\title{
Maintenance of familiarity and social bonding via communal latrine use in a solitary primate (Lepilemur leucopus)
}

\author{
Iris Dröscher • Peter M. Kappeler
}

Received: 24 July 2014 / Revised: 8 September 2014 / Accepted: 9 September 2014 / Published online: 16 October 2014

(C) The Author(s) 2014. This article is published with open access at Springerlink.com

\begin{abstract}
Latrine use (i.e., the repeated use of specific defecation/urination sites) has been described for several mammals, including carnivores, ungulates, and primates. However, the functional significance of latrine use in primates has not been studied systematically yet. We, therefore, followed 14 radio-collared individuals of the pair-living white-footed sportive lemur (Lepilemur leucopus) for 1097 hours of continuous focal observations to investigate latrine distribution, seasonality of latrine use, as well as age and sex of users to test various hypotheses related to possible functions of latrine use, including territory demarcation, resource defense, signaling of reproductive state, social bonding, and mate defense. All individuals of a social unit exhibited communal use of latrines located in the core area of their territory, supporting the social boding hypothesis. Latrine use seems to facilitate familiarity and social bonding within social units via olfactory communication in this primate that lives in family units but exhibits low levels of spatial cohesion and direct social interactions. In addition, frequency of latrine visitation was higher during nights of perceived intruder pressure, supporting the mate defense hypothesis. However, animals did not react to experimentally introduced feces from neighboring or strange social units, indicating that urine may
\end{abstract}

Communicated by D. P. Watts

Electronic supplementary material The online version of this article (doi:10.1007/s00265-014-1810-z) contains supplementary material, which is available to authorized users.

I. Dröscher $(\bowtie) \cdot$ P. M. Kappeler

Behavioral Ecology \& Sociobiology Unit, German Primate Center, Kellnerweg 4, 37077 Göttingen, Germany

e-mail: iris.droescher@gmail.com

P. M. Kappeler

Department of Sociobiology/Anthropology,

Johann-Friedrich-Blumenbach Institute of Zoology \& Anthropology,

University of Göttingen, Kellnerweg 6, 37077 Göttingen, Germany be the more important component of latrines than feces in this arboreal species. Based on a survey of latrine use and function in other mammals, we conclude that latrines facilitate communication particularly in nocturnal species with limited habitat visibility and in species where individuals are not permanently cohesive because they constitute predictable areas for information exchange.

Keywords Latrines $\cdot$ Olfactory communication $\cdot$ Scent marking $\cdot$ Intra-group communication $\cdot$ Mate defense . Primate

\section{Introduction}

Chemical signals can transmit a variety of information in vertebrates, such as species identity (Caspers et al. 2009), sexual identity (Ferkin and Johnston 1995), reproductive state (Ziegler 2013), and individual identity (Linklater et al. 2013). Many chemical signals derive from various excretory products, such as feces, urine, and gland secretions (Eisenberg and Kleiman 1972), and scent marking is defined as the application of these products to features in the environment (Macdonald 1980). The repeated use of specific locations for defecation/urination can result in an accumulation of feces and other excretory products at so-called latrine sites, and this behavior can be considered a special form of scent marking in cases where it serves a communicatory function (Wronski et al. 2013). Latrines have been described for several ungulates (e.g., Ourebia: Brashares and Arcese 1999; Tragelaphus: Apio et al. 2006; Mazama: Black-Decima and Santana 2011; Gazella: Wronski et al. 2013), carnivores (e.g., Suricata: Jordan et al. 2007; Vulpes: Darden et al. 2008; Meles: Kilshaw et al. 2009; Hyaena: Hulsman et al. 2010), primates (e.g., Lepilemur: Charles-Dominique and Hladik 1971; Cheirogaleus: Schilling 1980a; Hapalemur: Irwin et al. 
2004), and a few other mammalian taxa (e.g., Arvicola: Woodroffe and Lawton 1990; Oryctolagus: Sneddon 1991). Feces are either deposited alone (e.g., Bassariscus astutus: Barja and List 2006; Ourebia ourebi: Brashares and Arcese 1999) or together with urine and/or secretions of specialized glands at latrine sites (e.g., Meles meles: Roper et al. 1986; Mazama gouazoubira: Black-Decima and Santana 2011). In several species (e.g., Vulpes velox: Darden et al. 2008; Hyaena spp.: Gorman and Mills 1984; Meles meles: Stewart et al. 2002), urination is the most common mark used in this context, and feces per se may not be the most important information component of a latrine (Darden et al. 2008). Similarly, for arboreal species, one could reasonably expect that any potential communicatory function may be rather related to olfactory signals obtainable from arboreally deposited urine than from terrestrial accumulation of feces, which may rather be a byproduct of localized urine marking.

Among primates, the lemurs of Madagascar (Lemuriformes) represent a radiation whose members rely heavily on chemical signals for their social communication (Mertl 1976; Schilling 1979, 1980b; Perret 1992; Kappeler 1998; Heymann 2006b; Charpentier et al. 2008, 2010; Boulet et al. 2009, 2010; Crawford et al. 2009; Morelli et al. 2013), irrespective of their social organization (Kappeler and van Schaik 2002). The more than 20 species of sportive lemurs (genus Lepilemur) are all medium-sized nocturnal folivores. Like many other nocturnal lemurs, they exhibit urine marking (Schilling 1979, 1980b; Epple 1986). In addition, Lepilemur males possess anogenital scent glands, while females have no scent glands (Petter et al. 1977; Schilling 1979). Sportive lemurs are strictly arboreal, and patterns of defecation/ urination produce terrestrial accumulations of feces (CharlesDominique and Hladik 1971; Russel 1977; Irwin et al. 2004). Some species live in dispersed pairs, which are characterized by spatial overlap between one adult male and one adult female, but low cohesion between pair partners (Schülke and Kappeler 2003; Zinner et al. 2003; Méndez-Cárdenas and Zimmermann 2009; Hilgartner et al. 2012; Dröscher and Kappeler 2013). Pair partners living in dispersed pairs may never share sleeping sites or allogroom each other, and they may even show signs of active spatial avoidance (Dröscher and Kappeler 2013). In addition, sportive lemurs are highly territorial, as indicated by minimal home range overlap between individuals of neighboring social units (Zinner et al. 2003; Rasoloharijaona et al. 2006; Méndez-Cárdenas and Zimmermann 2009; Dröscher and Kappeler 2013). This combination of traits makes sportive lemurs an interesting taxon to study various potential functions of latrines.

Irwin et al. (2004) reviewed latrine behavior in primates and discussed several hypotheses for the function of latrine use. In particular, they suggested that latrine use in lemurs is mainly linked to the defense of resources, such as specific food patches, mates or sleeping sites. While male sportive lemurs exhibit mate guarding and defend their territories against neighboring males (Hilgartner et al. 2012), they do not defend food resources for their pair mates, and competition for food is low within as well as between social units (Dröscher and Kappeler 2014). However, systematic tests of this potential function of latrines have not been conducted yet.

While latrines may be merely a by-product of a bimodal defecation rhythm that results in the concentration of defecations being deposited under repeatedly used sleeping sites (Julliot 1996; González-Zamora et al. 2012), the use of localized defecation sites can also be explained by several additional, non-exclusive functional hypotheses. Many hypotheses that are commonly formulated for the function of scent marking (e.g., Ralls 1971; Kappeler 1998; Brady and Armitage 1999; Lazaro-Perea et al. 1999; Rostain et al. 2004; Heymann 2006a; Lewis 2006) are also applicable to the function of latrine use, as latrine behavior is a special form of olfactory communication.

In the following, we present hypotheses that are applicable to the social system of our study species (see below) and provide key references for each one of them. First, latrines may be used to demarcate territories, since many mammals are known to use urine, feces or other scent marks to delineate home range boundaries (Mertl-Milhollen 1979; Brashares and Arcese 1999; Stewart et al. 2001; "territory demarcation hypothesis"). Second, latrines may be used to communicate reproductive state, since male mammals seem to be able to detect chemical cues in female urine and/or feces related to reproductive state (Balestrieri et al. 2011; Archunan and Rajagopala 2013; "reproductive signaling hypothesis"). Third, latrines may serve to advertise the willingness to defend important resources such as food (Kruuk 1992; Miller et al. 2003; Remonti et al. 2011) or resting sites (Goszczynski 1990; Branch 1993; Brady and Armitage 1999; "resource defense hypothesis"). Fourth, latrines may function as information exchange centers for individuals that rarely associate or interact directly to facilitate the exchange of olfactory individualspecific information within social units to maintain social bonds (Kingdon 1982; Greene and Drea 2014; "social bonding hypothesis"). Finally, latrines may play a role in mate defense by advertising the commitment of resident males to defend resident females (Roper et al. 1986; Jordan et al. 2007; "mate defense hypothesis").

By detailing latrine density and distribution, seasonality and behavioral contexts of latrine use as well as age and sex of users, we aimed to test predictions of the above hypotheses. Specifically, (a) if latrines were used to demarcate territories, we expected that they would be located at territorial boundaries or in zones of home range overlap between neighboring social units rather than in core home range areas. (b) If latrines were used to communicate reproductive state, we predicted that frequency of latrine use would increase during the pronounced annual mating season. (c) If latrines were used to 
contribute to resource defense, we anticipated that latrines would be located in proximity to regular sleeping trees, that feeding effort would be higher within than outside the latrine area, and/or that animals would mark specific food trees by defecation/urination. (d) If latrines were used as information exchange centers for intra-group communication in a species in which individuals of a given social unit visit latrines independently, we expected all individuals of a social unit to visit the same latrines to facilitate information transfer. In addition, we predicted that latrines would be visited exclusively by individuals of a social unit, but not by individuals of neighboring units. (e) If latrines play a role in mate defense, we expected that the frequency of male latrine use would increase with perceived intruder pressure. In addition, we expected that males would place glandular scent marks preferentially in latrines. Finally, (f) since aggression in L. leucopus is directed towards roaming individuals rather than neighbors (Dröscher and Kappeler 2013), we expected individuals to react more strongly to experimentally introduced feces of strange individuals than to those of familiar ones (Ydenberg et al. 1988; Müller and Manser 2007).

\section{Methods}

Study site and animal capture We studied a population of white-footed sportive lemurs (Lepilemur leucopus) at Berenty $\left(\mathrm{S} 25.00^{\circ}, \mathrm{E} 46.30^{\circ}\right)$, an approximately $200 \mathrm{~km}^{2}$ private ecotourism reserve in southern Madagascar. We observed animals in a spiny forest fragment of about 5 ha (HAH Reserve Forestière parcel 1), which is connected to gallery forest on one side via a transitional forest and a further 40 ha spiny forest fragment on the other side (Norscia and Palagi 2008). To ensure continuing focal observations of single individuals, we equipped animals with radio-tracking transmitters. We used a blowpipe and $1 \mathrm{ml}$ air pressured narcotic syringe projectiles (Telinject, Germany) to anesthetize animals with $0.4 \mathrm{ml}$ Ketanest $(100 \mathrm{mg} / \mathrm{ml})$ in the mornings in their daytime sleeping sites. We fitted the animals with radio-collars (TW-3 button-cell tags, Biotrack, UK) while anesthetized. We kept the animals in an animal transport box until they were fully recovered and released them again at their capture site in the evening. We fitted 16 adult (eight males and eight females) and four subadult individuals (three males and one female) with radio-collars. We differentiated adult individuals from subadults by the degree of tooth wear and body mass. We did not radio-collar animals when radio-collars exceeded $4 \%$ of their body mass. We removed all radio-collars after the end of the study. The research followed standard protocols for animal handling, capture, and radio-tracking and was approved by the Commission Tripartite CAFF of the Ministry for Water and Forests (Madagascar).
Behavioral observations We collected behavioral and locational data between October 2011 and October 2012 for a total of 1530 hours on 20 radio-collared individuals. For the present study, we only considered focal individuals that were adult and belonged to social units in which both pair mates were radio-collared $(N=14$ individuals, observation time in sight $=$ 1097 hours). Five out of seven social units consisted of pairs; whereas in the remaining cases, an adult male was associated with two adult females each (social unit 1 and 3). However, these females had exclusive ranges since they were regularly seen within the range of the associated adult male, but never within the range of the other adult female. No behavioral observations could be conducted on these females because they were not equipped with radio-collars. For a detailed description on the identification of the social units within the study population see Dröscher and Kappeler (2013).

We divided the study period into four biologically relevant seasons: birth and offspring care with lactation (early wet season from November to January), offspring care without lactation (late wet season from February to April), mating and early gestation (early dry season from May to July) and late gestation (late dry season from August to October). Each individual was watched for two full nights during each season, once by the first author and once by a Malagasy research assistant, using a TR-4 receiver and a RA-14K antenna (Telonics, USA; Appendix A) to locate animals. However, we included data only for 7 observation nights for male $\mathrm{m} 9$ since he joined female $\mathrm{f} 2$ only after he displaced the previous resident male. Similarly, we include data only for 4 observation nights for male $\mathrm{m} 10$ since he only joined female f1B at the beginning of the mating season.

The trees of the spiny forest have small and exposed canopies (Grubb 2003), permitting nocturnal observation of the subjects clearly and continuously (Hladik and CharlesDominique 1974). We started continuous focal animal observations (Altmann 1974) when an animal left its sleeping site at dusk until it returned to its daytime sleeping site at dawn. Usually, when the first author watched an adult male, the Malagasy research assistant watched the corresponding adult female during the same night simultaneously and vice versa. An overview of the focal animal observations is given in Appendix A. We tagged spatial locations of animals during continuous focal observations with biodegradable tape while recording the beginning and end of each behavior (i.e., resting, travelling, grooming, feeding, displaying, social interactions). We determined the exact position of the tagged trees with reference to a $10 \times 10 \mathrm{~m}$ study grid system. In addition, we recorded all occurrences of defecation, urination, scent marking (i.e., rubbing of the anogenital region on a substrate) and olfactory inspection (i.e., sniffing and licking of substrate) of the focal animals along with their spatial location. We distinguished between single-use and multiple-use defecation sites by investigating the degree of ground coverage by feces ( $\mathrm{a}$ few 
scattered droppings that could have been produced by a single defecation event vs. concentrated accumulation of feces indicative of multiple use). In addition, ID recorded the same data every time she could observe an un-collared animal defecating/urinating. Each morning after a full-night follow, we located the sleeping trees of all radio-collared animals.

Experimental translocation of feces To establish whether animals discriminate between feces of their own, neighboring and strange social units, we conducted latrine translocation experiments in June 2013 with males and females of 5 social units. We gathered feces from latrines from known neighboring social units (i.e., "neighbor treatment") and from latrines we located in a neighboring forest parcel, to ensure that the feces originated from social units that were not familiar to the focal animals (i.e., "stranger treatment"). Similarly, we gathered feces from latrines of the focal social unit (i.e., "control treatment"). For the experiments, we spread the gathered feces on plastic sheets of approximately $1 \mathrm{~m}^{2}$ (i.e., "experimental latrine"). We handled the feces using disposable plastic gloves. To ensure that the focal animals would encounter the experimental latrines, we determined through preliminary observations which latrine tree each of the focal animals would visit first after leaving the day-time resting tree. For the experiments, we introduced the feces in proximity to the identified latrine tree before sunset. For each experiment, we used an approximately equal amount of feces. We started to record behavioral responses (i.e., loud calling, displaying, glandular scent marking, and sniffing) from the moment the focal individual entered the experimental latrine tree and continued behavioral observations for $30 \mathrm{~min}$. In addition, we recorded the amount of time the animal spent in the latrine tree. We randomized the order in which we presented the three experimental treatments to the focal individuals. We only conducted one experimental treatment on one social unit during a single night. We removed the plastic sheets with the experimental feces immediately after each experiment.

Data analyses To determine whether animals discriminate between feces of their own, neighboring and strange social units, we used Friedman's ANOVA to test for differences between experimental treatments. We used rates of loud calling, sniffing, displaying, and glandular scent marking as measures of response intensity in males, but only rates of loud calling and sniffing in females. A new bout started when an individual interrupted the behavior for more than $5 \mathrm{~s}$. In addition, we used the amount of time the animals spent in the experimental latrine tree as a response variable in both sexes. We based all calculations on the time the animals were in sight.

To establish the number and to investigate the distribution of latrines within the territories of the 7 social units, we calculated the size of individual annual home ranges with the Animal Movement extension of ArcView and plotted all recorded defecation/urination events. Since kernel densities do not require serial independence of observations, we did not correct for spatial autocorrelation (De Solla et al. 1999). However, we based our home range estimates on a constant time interval (i.e., $5 \mathrm{~min}$ ) that is biologically meaningful, since it allows individuals to traverse their home range at maximum speed (Rooney et al. 1998). We calculated home range size from $95 \%$ fixed kernel home range utilization distributions (Worton 1989) using ad hoc smoothing (Silverman 1986). To establish whether defecation/urination occurred anywhere in an animal's home range (i.e., random distribution of events) or were restricted to certain areas (i.e., clumped distribution of events), we used the nearest neighbor analysis as implemented in the Animal Movement extension for ArcView (Hooge and Eichenlaub 1997). While $R$ values of 1 indicate a random distribution, values of $<1$ and $>1$ indicate a tendency towards a clumped or a uniform distribution, respectively. Before running the analyses, we applied a small amount of random noise to the spatial location points of observed defecation/ urination events to break ties between repeated observations at the same localities using the function "jitter" of the R software (R Core Team 2012).

After ascertaining the spatial distribution of defecation/ urination events via nearest neighbor analysis as being clumped, we established the number of latrines per territory by visual inspection of the spatial features in ArcView. Specifically, we considered a latrine as a cluster of defecation/urination events that were at a distance of up to $6 \mathrm{~m}$ of each other. We choose $6 \mathrm{~m}$ as a distance criterion because this was the minimum distance at which a cluster of defecation/urination events would not disintegrate in a larger number of smaller, non-continuous latrines in close proximity to each other. When testing the various functional hypotheses of latrine use, we only considered defecation/urination events that were clearly associated with latrine visitations by removing all random defecation/urination events (i.e., single-use defecation sites that were not in proximity to a latrine; $N=32$ or $5 \%$ of all defecation/urination events recorded).

To test the territory demarcation hypothesis, we established the number of defecation/urination events within the core vs. the boundary area as well as in the zones of home range overlap. We delineated core areas using a time maximizing function derived from kernel analyses (Vander Wal and Rodgers 2012).

To test the resource defense hypothesis with regard to defense of food, we investigated whether animals spent less time feeding within than outside the latrine area. We defined food patches as single feeding trees in which animals were observed feeding. Each food patch that was located within $6 \mathrm{~m}$ of a latrine tree was assigned as being part of the general latrine area. We calculated the relative proportion of feeding time within and outside the latrine area for each focal 
individual. In addition, we calculated the relative proportion of the number of food patches located within and without the latrine area. We calculated an index of feeding effort that allows accounting for the fact that the latrine area is smaller than the remaining home range area, and hence, innately can only contain a smaller number of potential food patches. We divided the proportion of foraging time within the latrine area by the relative proportion of the number of food patches located within the latrine area to calculate an index of feeding effort inside the latrine area. Likewise, we divided the proportion of foraging time outside the latrine area by the relative proportion of the number of food patches located outside the latrine area to calculate an index of feeding effort outside the latrine area. We compared feeding effort within and outside the latrine area using Wilcoxon signed-ranks test for each focal individual.

To test the resource defense hypothesis with regard to defense of sleeping sites, we investigated spatial dependence between defecation/urination sites and regular sleeping sites (i.e., sleeping trees that were used more than once by the focal animals). We conducted the analyses using the R package "spatsat" (Baddeley and Turner 2005). We defined the union home range of all study individuals as the sampling window. We used the L-cross function to describe the dependence in bivariate point patterns using the independence approach (Dixon 2002). We used the inhomogeneous L-cross function to adjust for spatially varying intensity. For formal hypothesis testing, we computed simulation envelopes by pointwise Monte Carlo test. We used 99 simulations of CSR (complete spatial randomness) to compute envelopes. The theory of the Monte Carlo test requires the distance $(r)$ to be fixed in advance for hypothesis testing (Baddeley and Turner 2005). We used a value of $6 \mathrm{~m}$ as a critical distance. Spatial dependence between points of two types occurs when events of each type are either closer (clustering) or farther away (inhibition) than expected under the assumption that the two processes are independent. Likewise, to test the mate defense hypothesis we investigated spatial dependence between defecation/urination sites and male glandular scent marking sites.

To test the reproductive signaling hypothesis, we used linear mixed models (LMM) to estimate the effect of season on latrine use frequency (model 1). Since season may have a different effect on latrine use frequency in the two sexes, we included season, sex, and their interaction in the model. We included individual identity nested within social unit as a random effect to control for pseudo-replication. In addition, to test the mate defense hypothesis, we used LMM to estimate the effect of intruder pressure on latrine use frequency in males (model 2). We considered observation nights in which focal males engaged in display behavior (i.e., branch bashing displays accompanied by loud calling) and/or placed glandular scent marks as nights with perceived intruder pressure. For each full-night observation, we calculated the frequency of latrine use by dividing the number of latrine visits by the amount of time the focal animal was in sight. We included individual identity as a random effect to control for repeated observations. We controlled for the effect of the number of latrines within an individual's home range as well as for the effect of the type of social organization the individual lived in (i.e., pairs vs. one-male, two-female units). We transformed response variables using the function "boxcox" of the package "MASS" (Venables and Ripley 2002) and $z$-transformed the covariate (i.e., number of latrines; Schielzeth 2010).

We checked the distribution of the model residuals, plotted residuals against predicted values, conducted the Levène's test and correlated absolute residuals with fitted values to check model validity. We visually inspected qqplots and plots of residuals vs. fitted values. None of the diagnostics indicated deviations from the assumptions of normality and homogeneity of residuals (Quinn and Keough 2002; Field et al. 2012). We calculated Variance Inflation Factors (VIFs) using the R function "vif" of the package "car" (Fox and Weisberg 2011) running a standard linear model with the random effect excluded from the predictors. VIFs indicated collinearity not to be an issue (largest VIF for model $1=2.03$ and for model $2=$ 1.35, respectively; Field et al. 2012). For influence diagnostics (Cook's distance, dfbetas), we used the R package "influence.ME" for mixed effect models (Nieuwenhuis et al. 2012). The largest Cook's distance was only 0.14 for model 1. However, Cook's distances indicated some problems with model stability for model 2 (largest Cook's distance $=1.55$ ). Similarly, unstandardized DFBeta values reached 1.15 for model 2 , whereas values did not indicate any problems for model 1 (largest DFBeta=0.68; Quinn and Keough 2002; Field et al. 2012). Running the second model without the influential case (male 4) did not lead to a different overall result, and hence, we report the results obtained for the complete dataset. To test whether season or intruder pressure, respectively, had an overall effect on latrine use frequency we compared the full model to a model in which only these predictors were removed (i.e., season and its interaction with sex or perceived intruder pressure, respectively), using a likelihood ratio test. We fitted the models in $R$ using the function "Imer" in the package "Ime4" (Bates et al. 2012) using Maximum Likelihood rather than Restricted Maximum Likelihood to achieve more reliable $P$ values (Bolker et al. 2008). We derived $P$ values for the individual effects based on Satterthwaite approximation for denominator degrees of freedom by using the function "summary" of the R package "ImerTest" (Kuznetsova et al. 2014). We considered $P \leq 0.05$ as statistically significant. 


\section{Results}

General latrine behavior Animals remained on average 5.8 \pm $9.4 \mathrm{~min}($ mean $\pm \mathrm{SD} ; N=678)$ in trees in which they defecated/ urinated. Similarly, they spent in total only $6 \%$ of the total observation time they were in sight in trees in which they defecated/urinated. They lifted their tail to defecate and urinate while clinging to tree trunks. While the feces dropped to the ground, the urine dripped down the main trunk of the tree and left visible stains even once the urine was dried. While Lepilemur feces were not very odorous, at least to the human nose, urine was characterized by a distinct species-specific odor. We could observe the focal animals on two occasions to lick and on 26 occasions to sniff the bark of a tree. On 15 of these occasions this behavior occurred in the general latrine area and on six occasions in an identified latrine tree. Outside the observation period, we could observe a male to sniff a wet urine stain that was deposited 8 min earlier by a female in the latrine. In addition, we could observe the animals on four occasions to lower themselves to less than $1 \mathrm{~m}$ above the ground in a latrine tree to inspect the ground.

Experimental translocation of feces The time spent in the experimental latrine ranged between $11 \%$ and $80 \%$ (mean $\pm \mathrm{SD}=29 \pm 23$ ) of the observation time in females and between 11 and $39 \%(20 \pm 7)$ in males. Rates of loud calling ranged between 0 and 2 bouts/h in females $(0.14 \pm 0.55)$ and males $(0.27 \pm 70)$. While we could not observe females to engage in sniffing, rates of sniffing ranged between 0 and 8 bouts $/ \mathrm{h}$ in males $(1.21 \pm 2.49)$. We could not observe males to engage in display behavior during the experiment, but rates of scent marking ranged between 0 and 2 bouts/h $(0.54 \pm 0.92)$. Response intensity did not differ significantly among the three experimental treatments in either males or females. More precisely, the amount of time spent in the latrine tree (females, $\chi^{2}=1.3, d f=2, P=0.522$; males, $\chi^{2}=5.7$, $d f=2, P=0.058$ ), rates of loud calling (females, $\chi^{2}=0.3$, $d f=2, P=0.861$; males, $\left.\chi^{2}=0.3, d f=2, P=0.861\right)$, sniffing (females, $\chi^{2}=0.0, d f=2, P=1$; males, $\chi^{2}=1.2, d f=2, P=$ 0.549 ), displaying (males, $\chi^{2}=0.0, d f=2, P=1$ ), and scent marking (males, $\chi^{2}=1.2, d f=2, P=0.549$ ) did not differ significantly among treatments.

Spatial distribution of defecation/urination events Union home range size (95\% Kernel estimates) for the seven social units ranged between 0.28 and 0.47 ha (mean $\pm \mathrm{SD}=0.38 \pm$ 0.07 ha, $N=7$ ). Nearest neighbor analyses of the locations of defecation/urination events computed $R$ values ranging between 0.15 and 0.48 for the union home ranges. Within all seven union home ranges the spatial distribution of the defecation/urination events differed significantly from a random spatial distribution $(P<0.001, N=7)$, with a tendency towards clumping as opposed to towards an even distribution (Table 1). We identified 3 to 4 latrines in each union home range (Fig. 1).

Territory demarcation hypothesis We recorded a total of 678 defecation/urination events. Using the time maximization function, core areas of individual ranges were delineated by $65 \%$ isopleths. Union core areas (65\% Kernel estimates) represented $26 \pm 6 \%$ (range $=20-37 \%, N=7$ ) of the union home ranges (95\% Kernel estimates) of the social units. However, the majority of defecation/urination events (mean $\pm \mathrm{SD}=82 \pm 7 \%$; range $=72-94 \%, N=7$ ) were located within the small union core areas of the social units, so that the density of defecation/urination events was significantly higher in the core area (mean $\pm \mathrm{SD}=875 \pm 391$ events/ha) compared to the remaining home range area $(72 \pm 54$ events/ha; Wilcoxon signed-rank test, $V=28, P=0.016, N=7)$. The overlap zones comprised only $1.35 \%$ of the union of all individual home ranges. None of the defecation/urination events were located within overlap zones of neighboring territories.

Resource defense hypothesis The relative proportion of foraging time within the latrine area ranged between $22 \%$ and $43 \%($ mean $\pm \mathrm{SD}=31 \pm 7 \%, N=14)$. The relative proportion of the number of patches located within the latrine area ranged between $23 \%$ and $46 \%(34 \pm 7 \%)$. The index of feeding effort inside the latrine area ranged between 0.7 and $1.1(0.9 \pm 0.1)$ and between 0.8 and $1.1(0.9 \pm 0.1)$ for the feeding effort outside the latrine area. Feeding effort within the latrine area did not differ significantly from the feeding effort outside the latrine area (Wilcoxon signed-ranks test, $V=56, N=14, P=$ 0.851 ). The animals spent only between $2 \%$ and $14 \%$ (mean $\pm \mathrm{SD}=7 \pm 4 \%, N=14$ ) of the total feeding time eating in identified latrine trees. While we could record a total number of 1,584 food patches throughout the study, animals were only seen to defecate/urinate in 79 of them. In addition, animals were observed to forage in only $41 \% \pm 11 \%$ (range $=24 \%$ $55 \%, N=14$ ) of the identified latrines trees.

Table 1 Spatial distribution of observed defecation/urination events within the union home ranges of seven social units of Lepilemur leucopus based on nearest neighbor analysis

\begin{tabular}{lllll}
\hline Social unit & \# defecation events & $Z$ value & $R$ value & $P$ value \\
\hline 1 & 100 & -13.59 & 0.22 & $<0.001$ \\
2 & 135 & -16.73 & 0.17 & $<0.001$ \\
3 & 112 & -12.75 & 0.23 & $<0.001$ \\
4 & 72 & -8.09 & 0.48 & $<0.001$ \\
5 & 86 & -11.34 & 0.35 & $<0.001$ \\
6 & 115 & -17.20 & 0.15 & $<0.001$ \\
7 & 90 & -13.91 & 0.22 & $<0.001$ \\
\hline
\end{tabular}


Fig. 1 Ninety-five percent kernel annual home ranges for individual adult males $(m)$ and females $(f)$ of Lepilemur leucopus at Berenty between October 2011 and October 2012 as well as the spatial arrangement of the latrines within the home ranges. Dots represent individual latrines trees, whereas the shaded areas represent a contagious buffer of $3 \mathrm{~m}$ around individual latrine trees to distinguish discrete latrines. Home ranges of pair partners overlap (Sex, $m=$ male, $f=$ female)

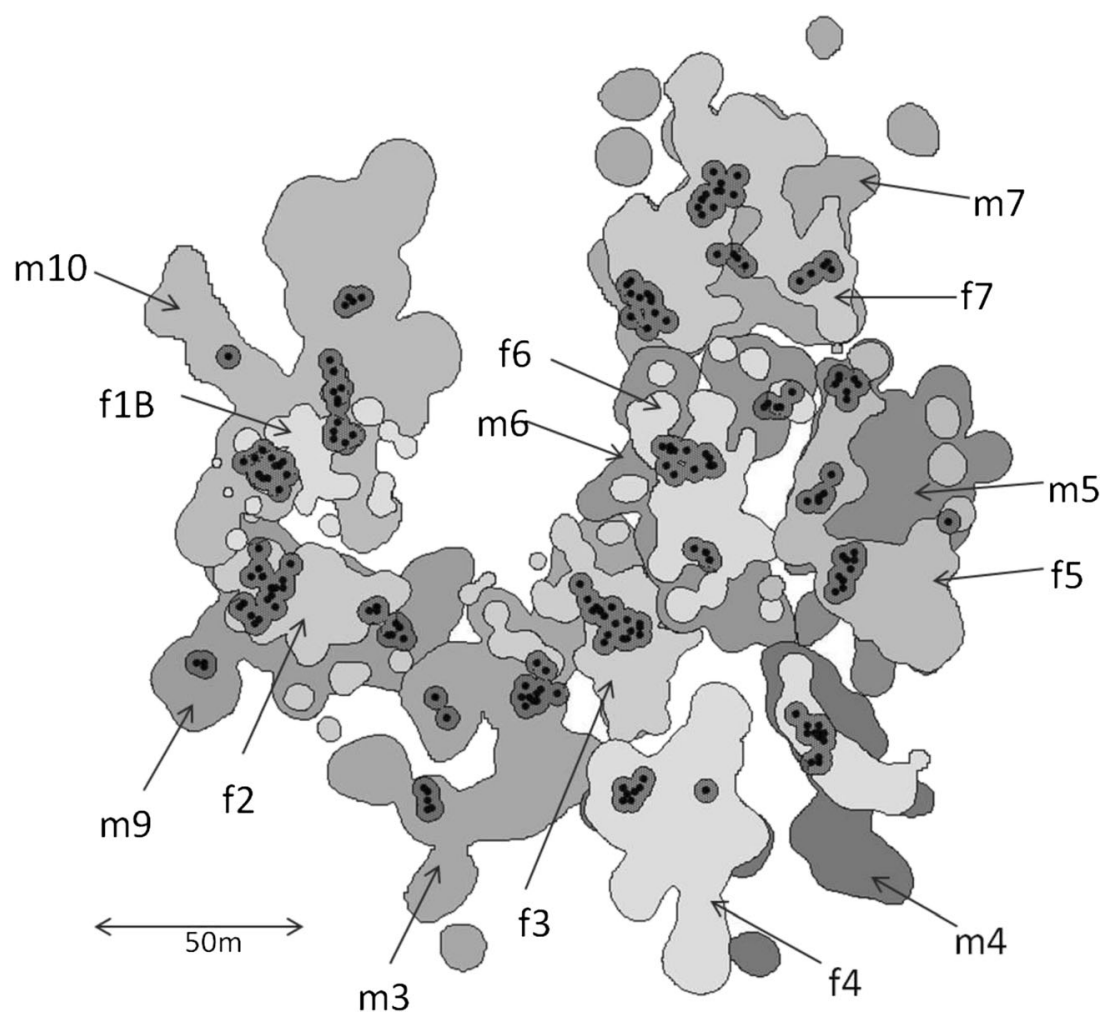

The number of repeatedly used sleeping trees ranged between 5 and $10($ mean $\pm S D=7 \pm 2)$ for the 7 social units. None of the latrine trees served as a sleeping tree. The computed empirical homogenous L-cross function fell within the simulation envelop at the critical distance of $6 \mathrm{~m}$, indicating spatial independence between defecation/urination and sleeping sites (Fig. 2).

Social bonding hypothesis Regarding the social units consisting of one adult male and two adult females (unit 1 and 3), all latrines located within the common range of the focal male and focal female were shared by both adult individuals. All latrines within the home ranges of social units consisting of one male and one female were shared by both pair partners, with the exception of social unit 2 where only 2 of 3 latrines were shared. We only once saw a focal individual (m6) to visit a neighbor's latrine (unit 7). In addition, we recorded 47 defecation/urination events by un-collared individuals. 46 of these defecation/urination events were associated with an identified latrine. In 41 of these cases, it was the offspring, which ranged within the parental territory. In 6 cases, it was the second adult un-collared female of unit 1 and 3 , respectively. In total, we could observe co-use by uncollared individuals in 18 out of 25 identified latrines.

Reproductive signaling hypothesis Latrine use frequency (number of latrine visitations/h) equaled $0.58 \pm 0.25$ (mean \pm $\mathrm{SD} ; N=25)$ during the early wet, $0.48 \pm 0.21 \quad(N=26)$ during the late wet, $0.48 \pm 0.19(N=28)$ during the early dry and 0.55 $\pm 0.19(N=28)$ during the late dry season. The result of the LMM to estimate the effect of season on latrine use frequency (model 1) indicated that the full model containing the effects

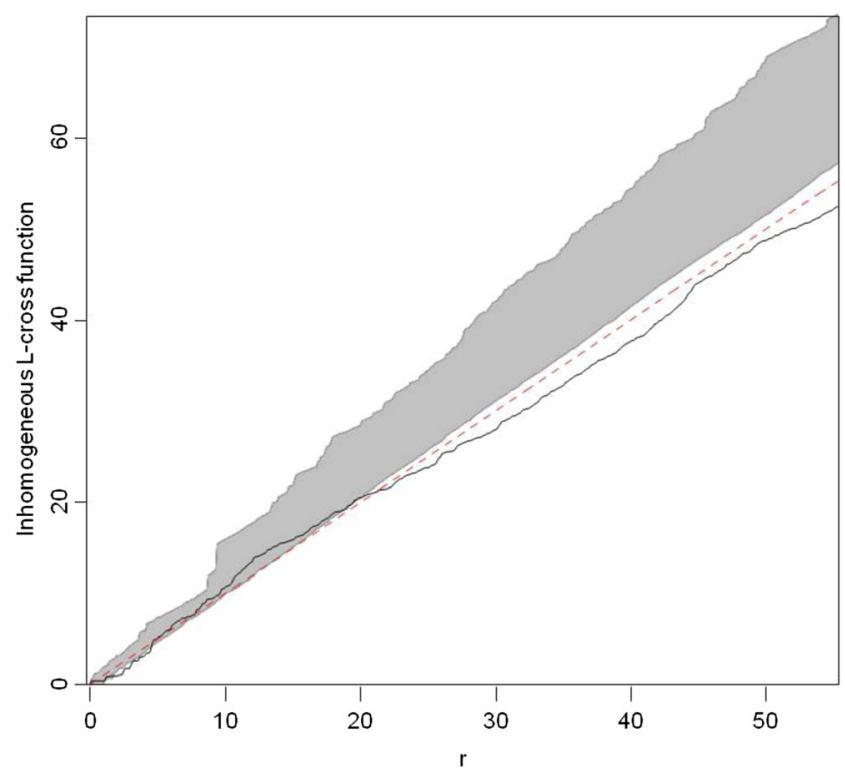

Fig. 2 Estimated inhomogeneous L-cross function and envelopes for the bivariate point pattern consisting of defecation/urination sites and sleeping trees. The solid line indicates the empirical L-cross function, the dotted line indicates the theoretical value for complete spatial randomness (CSR), and the gray band indicates the envelope from 99 simulations and $r$ is the distance argument 
of season and its interaction with sex was not significantly better in explaining the data than the null model (likelihood ratio test, $\chi^{2}=8.639, d f=7, P=0.279$ ).

Mate defense hypothesis During 25 observations nights, we observed focal males to place anogenital scent marks and during 21 nights they engaged in branch bashing and vocal displays. One or both of these behaviors were recorded during 37 out of 51 observation nights on adult males. The result of the LMM to estimate the effect of perceived intruder pressure (as indicated by display and scent marking behavior) on latrine use frequency in males (model 2) showed that the full model was significantly better in explaining the data than the null model (likelihood ratio test, $\chi^{2}=6.3327, d f=1, P=0.012$ ). Latrine use frequency was significantly increased in males during nights of perceived intruder pressure (mean frequency of latrine visitation $\pm \mathrm{SD}$ : nights with intruder pressure $=0.60 \pm$ 0.27 latrine visitations $/ \mathrm{h}$, nights without intruder pressure $=$ $0.46 \pm 0.18 ; \mathrm{P}=0.011$; Table 2). In total, we recorded 50 scent marking events by the 7 focal males. 32 of these scent marks were placed in an identified latrine tree. At the critical distance of $6 \mathrm{~m}$, the computed empirical inhomogeneous L-cross function fell above the simulation envelop, indicating spatial dependence (attraction) between latrines and scent marking locations (Fig. 3).

\section{Discussion}

Our study revealed that defecation/urination events were highly clustered in space, resulting in 3-4 latrines with terrestrial accumulations of feces in each territory. The study animals spent only a notably short time in trees they visited for defecation/urination, and therefore, the formation of latrines is not a mere by-product of animals remaining for a considerable time in a few preferred resting trees (Charles-Dominique and Hladik 1971; Schilling 1979). The number and locations of latrines were stable throughout the study period. We tested whether terrestrial accumulations of feces in an arboreal species can be considered to have an olfactory signaling function. We found no support for this notion and conclude that urine, which is more accessible to the animals for olfactory investigation, is the more important

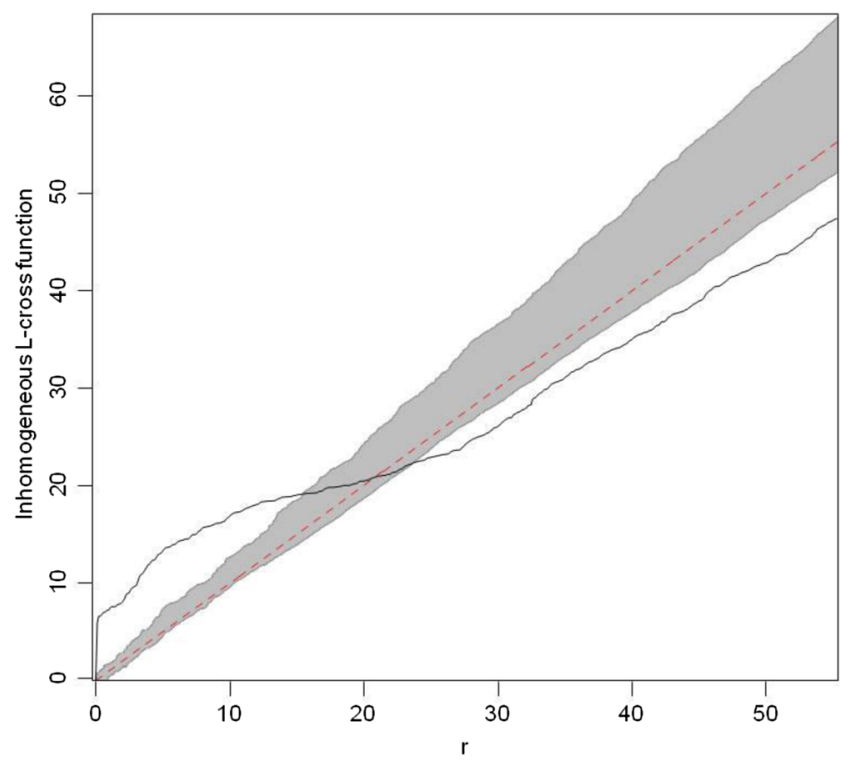

Fig. 3 Estimated inhomogeneous L-cross function and envelopes for the bivariate point pattern consisting of defecation/urination and scent marking sites. The solid line indicates the empirical L-cross function, the dotted line indicates the theoretical value for complete spatial randomness (CSR), the gray band indicates the envelope from 99 simulations, and $r$ is the distance argument

latrine component in this species. Additionally, we found empirical support for the hypotheses that latrines function in social bonding and mate defense, but a potential function in territory demarcation, resource defense, and signaling of reproductive state could not be shown. Below, we discuss these findings in relation to the social system of L. leucopus and in light of available data for other latrine-using mammals.

Experimental translocation offeces Most species that exhibit latrine use are terrestrial, and feces are, therefore, assumed to be salient sources of olfactory signals. However, L. leucopus did not react differently to experimentally introduced feces from neighboring or strange social units, compared to feces from familiar animals. In contrast, river otters (Lontra canadensis) investigate foreign scat more than local one when added to latrines (Oldham and Black 2009). Brown brocket deer (Mazama gouazoubira) investigate introduced dung from unknown individuals of the same sex significantly more than their own dung, and males counter-mark introduced dung with a greater frequency than females (Black-Decima and
Table 2 Effects of perceived intruder pressure, number of latrines, and social organization on latrine use frequency in male Lepilemur leucopus (LMM)

\begin{tabular}{llllll}
\hline Fixed Factor & $\beta$ & $\mathrm{SE}$ & $d f$ & $t$ & $P$ \\
\hline Intercept & 1.019 & 0.002 & 9.55 & 473.012 & $\mathrm{NA}$ \\
Intruder pressure perceived (yes) & -0.005 & 0.002 & 44.44 & -2.658 & 0.011 \\
Number of latrines & 0.003 & 0.002 & 6.69 & 1.474 & 0.186 \\
Social organization (1 $\lesssim$ and 2 ○) & -0.007 & 0.004 & 7.49 & -1.672 & 0.136 \\
\hline
\end{tabular}


Santana 2011). Badgers (Meles meles) respond more intensely towards foreign feces, and the response is greatest during the breeding season (Palphramand and White 2007). Among primates, only Cheirogaleus spp. produce arboreal latrines by smearing feces on branches during repeated walking defecation, resulting in a fecal accumulation adhering to the branch (Petter 1962). In arboreal species, such as L. leucopus, terrestrial latrines may serve as an optical signal (Irwin et al. 2004). Moreover, urination above ground facilitates dispersal of the odor by wind and increases the evaporating surface as the urine drips downward (Sillero-Zubiri and Macdonald 1998). Because urine marking is an ancestral behavior in strepsirrhine primates (Delbarco-Trillo et al. 2001), more experimental studies of urine communication in solitary and nocturnal species are called for.

Social bonding Scent marks may function as selfadvertisement and simply signal an individual's presence and identity to mates, family members, neighbors, and/or intruders (Eisenberg and Kleiman 1972; Peters and Mech 1975; Wolff et al. 2002), and latrines may serve as information exchange centers of individual-specific information (Darden et al. 2008; Black-Decima and Santana 2011). Latrines are maintained by all individuals of a social unit in L. leucopus. In contrast, in European badgers (Meles meles), a species in which latrines function mainly in territorial defense and demarcation, sexually immature juveniles rarely defecate/urinate at latrines (Brown et al. 2009). Latrines have been suggested to help maintaining social bonds in some ungulates such as steenbok (Raphicerus campestris), oribi (Ourebia ourebi), and dikdik (Madoqua kirkii; Kingdon 1982; Apio et al. 2006). Behaviors that facilitate familiarity, and hence, intragroup recognition may be especially important in solitary foragers with minimal direct social contact between individuals (Dröscher and Kappeler 2013). In contrast, mated pairs of swift foxes (Vulpes velox) exhibit high levels of den sharing that allows the exchange of information within the pair and to maintain the pair bond. Thus, latrines are not considered important for intra-pair communication and maintenance of social cohesion in $V$. velox (Darden et al. 2008). Latrine locations within the core areas of L. leucopus also support the idea that they function in social bonding since this form of placement should be particularly suited for information exchange between group members (Wronski et al. 2013).

In Coquerel's sifakas (Propithecus coquereli), the quality of the pair bond of breeding pairs is reflected in their olfactory signals by chemical convergence, possibly due to similar volatile production by shared microbial communities obtained through the exchange of odorant-producing microbes for example via overmarking (Greene and Drea 2014). Similarly, anal gland secretions that coat or saturate badger feces seem to have a group-specific chemical composition (Davies et al.
1988). Analogously, convergence in vocal signals facilitates group and pair cohesion in some primate and avian species (Geissmann and Orgeldinger 2000; Tyack 2008; Sewall 2009; Candiotti et al. 2012). Sportive lemurs not only exchange chemical but also acoustic signals. While pairs of the Milne Edwards' sportive lemur (L. edwardsi) coordinate loud calls in duets, perhaps to strengthen pair bonds (Méndez-Cárdenas and Zimmermann 2009), neither red-tailed sportive lemurs (L. ruficaudatus; Fichtel and Hilgartner 2013) nor L. leucopus exchange vocalizations in coordinated duets. In addition, males and females of L. leucopus produce sexspecific loud calls and thus are not available for vocal convergence. It, therefore, remains to be determined what exactly social bonding entails in different species and which aspects of it can be communicated in different modalities.

Mate defense Latrines may play a role in mate defense by advertising the commitment of resident males to defend coresident females (Roper et al. 1986; Jordan et al. 2007). We found that male latrine use frequency increased during nights of perceived intruder pressure. Likewise, latrine use frequency increases in meerkats (Suricata suricatta) when prospecting males are present (Jordan et al. 2007). In European badgers (Meles meles), males visit boundary latrines more often than females (Roper et al. 1993; Stewart et al. 2001), presumably to signal their commitment to guarding females of their own social group (Roper et al. 1986). Similarly, male brown brocket deer defecate/urinate more often after detecting dung from unknown individuals near one of their latrines. By re-marking their latrine, residents are thought to affirm their dominant or resident status (Black-Decima and Santana 2011).

We do not have systematic data on the behavior of intruders. However, outside the focal observation period, we could observe a resident and a roaming male to repeatedly visit the same latrine tree to defecate, urinate and place glandular scent marks. Male scent marking is linked to intra-sexual competition in several species (e.g., Microtu sp.: Jannett 1986; Myocastor coypus: Gosling and Wright 1994; Lemur catta: Kappeler 1998), and by strategically placing anogenital scent marks in latrines, which are composite olfactory signals of all members of a group, males of L. leucopus may also signal their competitive ability and willingness to defend their social unit to intruders (Rich and Hurst 1998).

Signaling of reproductive state Males are often able to detect chemical cues in female urine and/or feces related to reproductive state (Rasmussen et al. 1982; Ghosal et al. 2012; Archunan and Rajagopala 2013). Contrary to our predictions, frequency of latrine use in L. leucopus did not increase during the mating season. In contrast, genets (Genetta genetta) exhibit increased scat deposition at latrine sites during the mating period (Barrientos 2006). Similarly, latrine visitation peaks during the mating season in M. meles (Pigozzi 1989; 
Roper et al. 1993). While females may scent mark to advertise their reproductive state to attract males (Converse et al. 1995; Heymann 1998; Kappeler 1998), males may mask female scent to hide their oestrous condition from competing males or to advertise their presence to other males (Trumler 1958; Klingel 1974; Rich and Hurst 1998; Lewis 2005; Jordan et al. 2007). Although we cannot exclude the possibility that reproductive status may be communicated at latrine sites in L. leucopus, the function of latrine use does not appear to be specifically related to male attraction or to over-marking signals of estrous females, since neither females nor males increased latrine use frequency during the mating season. However, estrus in sportive lemurs is seasonal and short (Randrianambinina et al. 2007; Hilgartner et al. 2008) and any effect may have been concealed by our method of data collection, because we did not follow pairs when females were apparently in estrus.

Territory demarcation Urine and feces are common, readily available materials and many mammals use them to demarcate their territories or home ranges (e.g., Meles meles; Pigozzi 1989; Panthera tigris: Smith et al. 1989; Ourebia ourebi: Brashares and Arcese 1999). We found that the majority of defecation/urination events were localized within the core areas of the territories, even though L. leucopus is highly territorial (Dröscher and Kappeler 2013). However, where latrines cannot be economically maintained because territory borders are too long, they should be placed in the centre of the territory (Jordan et al. 2007). For example, brown hyenas (Hyaena brunnea) exhibit boundary marking when they live in small territories but display center marking if they inhabit large territories (Mills and Gorman 1987). Since territory size in L. leucopus is only 0.3 ha and individuals can easily traverse their territories in no more than $5 \mathrm{~min}$, it is unlikely that territory size in this species would preclude a border marking strategy. In M. meles, latrine use is primarily concentrated along territory boundaries and these are shared by members of the same and neighboring groups (Kilshaw et al. 2009) and are visited mainly by males (Roper et al. 1993). Besides boundary latrines, badgers also use hinterland latrines, which are visited by both sexes (Roper et al. 1993). In L. leucopus, all latrines were visited by both pair partners. Furthermore, we could observe only once a focal animal to visit a neighboring latrine, indicating that latrines in L. leucopus are not used for inter-group information transfer to monitor occupancy of surrounding territories (Jordan et al. 2007). Instead of latrines, sportive lemurs seem to use vocalizations to signal occupancy and to regulate spacing within and between social units (Rasoloharijaona et al. 2006; Fichtel and Hilgartner 2013).

Resource defense Resources such as resting sites (Goszczynski 1990; Branch 1993; Brady and Armitage
1999) and food trees may be marked to identify ownership and to deter conspecifics (Kruuk 1992; Miller et al. 2003). Contrary to our prediction, spatial locations of latrine trees and sleeping trees were spatially independent from each other, notwithstanding the fact that sportive lemurs only use a few selected sleeping sites and appropriate sleeping sites are limited, potentially leading to competition within or between social units (Rasoloharijaona et al. 2003, 2008). Establishing ownership of sleeping sites, therefore, may be beneficial to individuals by ensuring protection from predators or adverse climatic conditions (Franklin et al. 2007). For example, weasel sportive lemurs (L. mustelinus) gouge trees after leaving sleeping sites and before moving around, suggesting that they use non-nutritive tree gouging to display ownership of sleeping sites (Rasoloharijaona et al. 2010). Tree gouging behavior is absent in L. leucopus, and if latrines were to function instead for sleeping site defense, one would expect latrine trees to be in proximity to sleeping trees. Conversely, scent marks can potentially be exploited by predators to localize prey (Cushing 1984; Viitala et al. 1995), and an intentional placement of latrine trees in proximity to sleeping trees would seem to be disadvantageous in terms of predator attraction. In addition, animals may mark food trees as a means of asserting ownership of food resources.

Communal use of latrines in L. leucopus rejects the idea that they are used to signal resource use among members of a social unit. In contrast, otters (Lutra lutra) deposit spraints (i.e., token feces) to signal the use of feeding areas exploited by each individual (Kruuk 1992). Alternatively, members of a social unit of L. leucopus may use latrines to signal to other social units their willingness to defend their food resources. However, L. leucopus did not preferentially defecate/urinate in food trees since animals were observed to defecate/urinate in only $5 \%$ of all identified food patches and to feed in less than $50 \%$ of the identified latrine trees. In addition, the fact that individual feeding effort was equally distributed within and outside the latrine area indicates that latrines are not used to mark important feeding areas. These results are in line with the observation that L. leucopus exhibits low dietary selectivity, relies on the most common food species, and rarely engages in conflict over food neither within nor between social units (Dröscher and Kappeler 2014).

\section{Conclusions}

Latrines are found in solitary, pair-, and group-living mammals (Table 3). Latrine use appears to be common among species that are nocturnal, exhibit a dispersed social system, and are territorial. Since many species do not just defecate, but often also urinate and deposit glandular secrets at latrine sites, these signals may function to convey more than one message. 


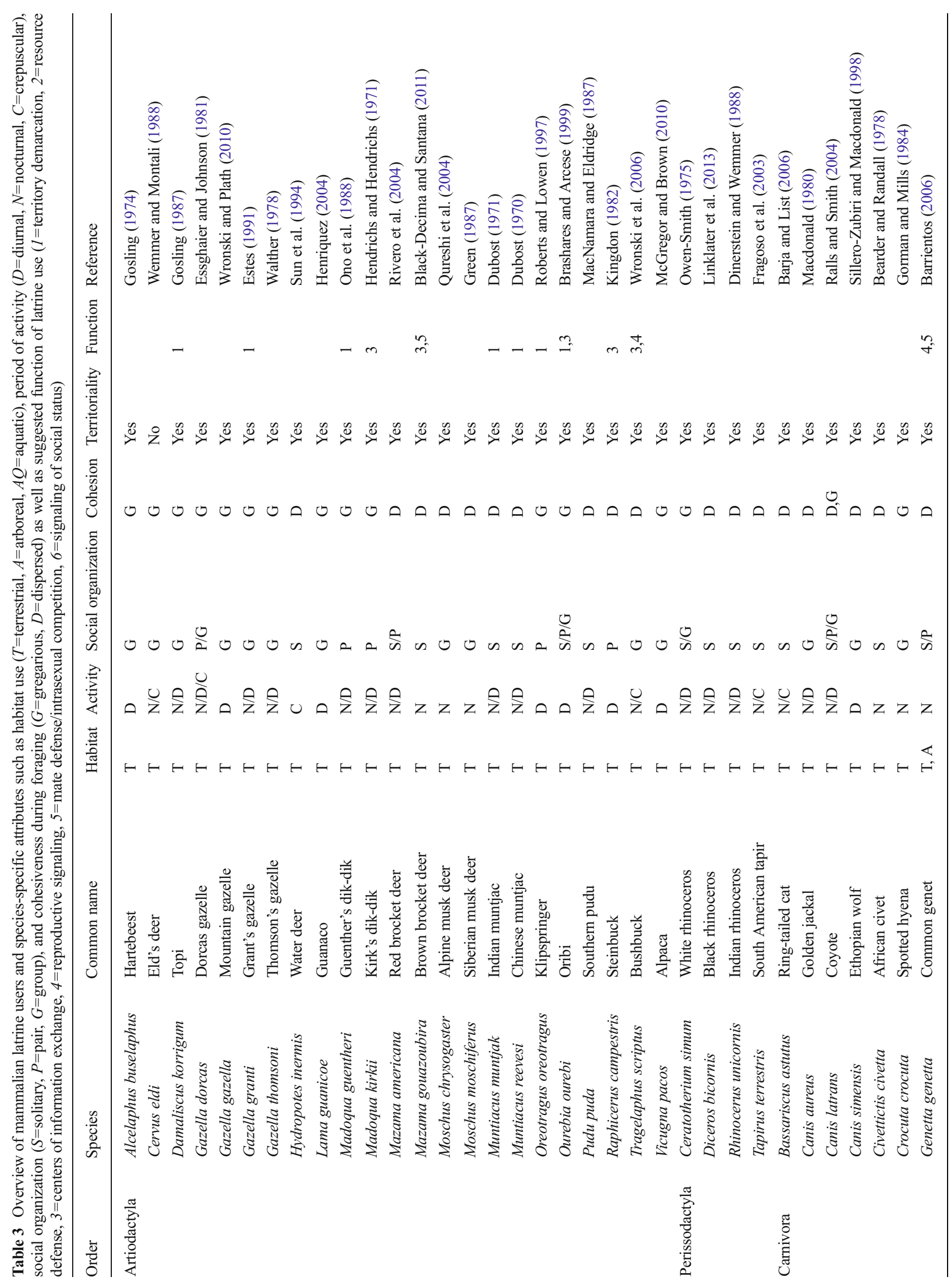




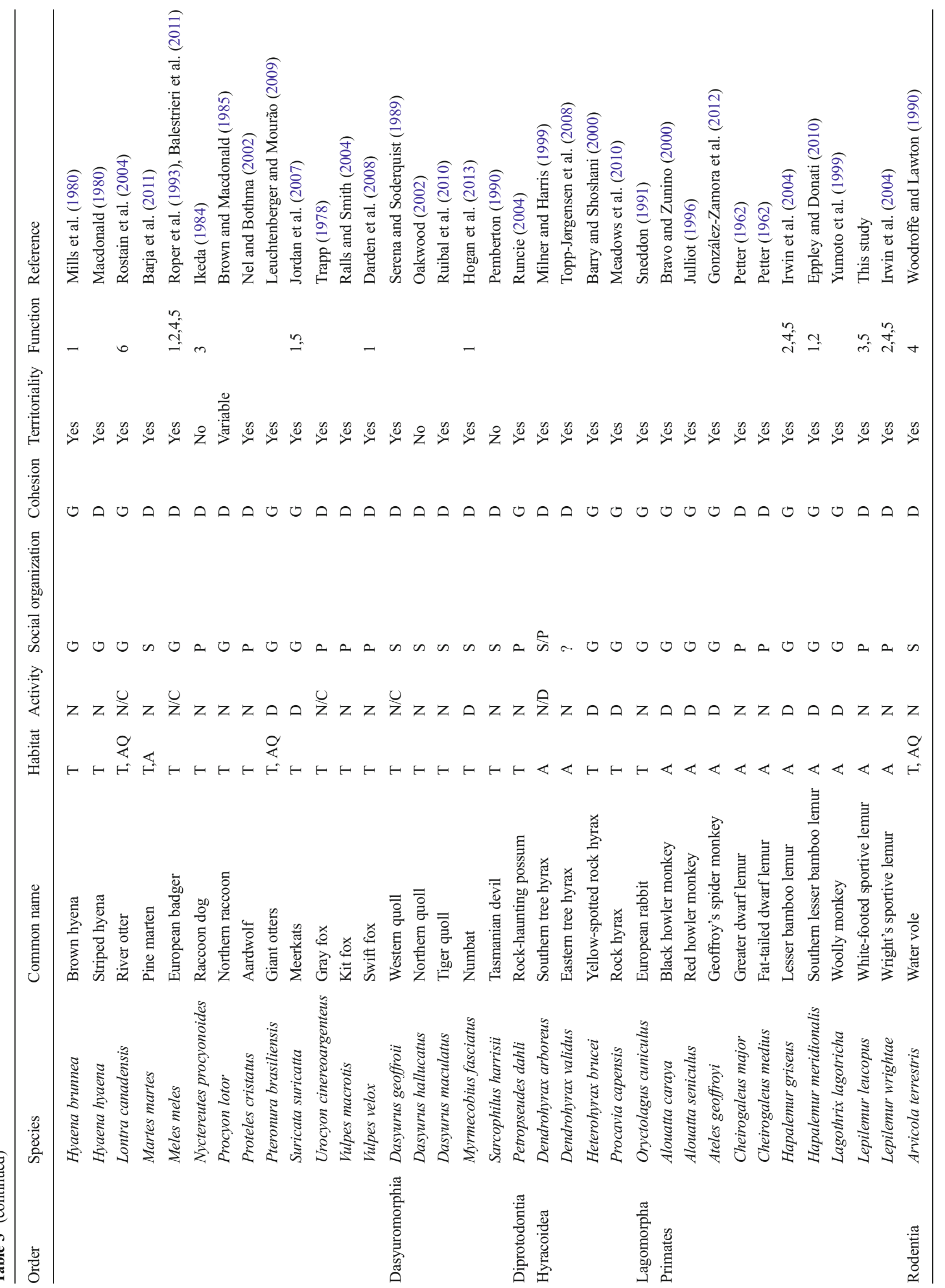


Especially in arboreal species with terrestrial accumulations of feces, urine may be of greater importance for chemical signaling than feces. Despite comparative data being sparse, a general pattern emerges that latrines are used in intra-specific olfactory communication in many cases. Although not restricted to nocturnal species, latrine use may facilitate communication in species with limited habitat visibility. Furthermore, latrines can be considered to be economical in species with low inter-individual cohesion, since individuals can benefit from predictable areas for information exchange. Notwithstanding the fact of being more common among territorial species, latrine use does not appear to necessarily function in territory demarcation. Clearly, more experimental studies are required to investigate the relative importance and functions of different modes of olfactory signaling at latrine sites.

Acknowledgments We wish to thank the de Heaulme family for the permission to study the sportive lemurs and for accommodation at Berenty Nature Reserve. We thank Dr. Daniel Rakotondravony, Dr. Rodin Rasoloarison, and the other members of the Département Biologie Animale de l'Universite d'Antananarivo for their cooperation and administrative support. We are grateful to blow-darting expert Mamitiana Razafindrasamba as well as Mahamaro and Jo from Berenty for help during animal capture. We especially thank field assistant Mahefa Mbeloamanitra Rahajarivony for continued assistance during data collection and Sonomena for daily care. We thank Hajarimanitra Rambeloarivony for logistic support in the field as well as for helpful discussions. The research permit was provided by Commission Tripartite CAFF (Madagascar). Financial support was provided by the German Primate Center Göttingen and the DFG (KA 1082/21-1).

Ethical standards This study complies with Malagasy and German regulations regarding the ethical treatment of research subjects.

Conflict of interest The authors declare that they have no conflict of interest.

Open Access This article is distributed under the terms of the Creative Commons Attribution License which permits any use, distribution, and reproduction in any medium, provided the original author(s) and the source are credited.

\section{References}

Altmann J (1974) Observational study of behaviour: sampling methods. Behaviour 49:227-267

Apio A, Plath M, Wronski T (2006) Localised defecation sites: A tactic to avoid re-infection by gastro-intestinal tract parasites in bushbuck, Tragelaphus scriptus? J Ethol 24:85-90

Archunan G, Rajagopala T (2013) Detection of estrus in indian blackbuck: behavioural, hormonal and urinary volatiles evaluation. Gen Comp Endocrinol 181:156-166

Baddeley A, Turner R (2005) Spatstat: An R package for analyzing spatial point patterns. J Stat Softw 12:1-42

Balestrieri A, Remonti L, Prigioni C (2011) Observations on marking behaviour in a low-density population of European badgers (Meles meles). Acta Ethol 14:65-68
Barja I, List R (2006) Faecal marking behaviour in ringtails (Bassariscus astutus) during the non-breeding period: spatial characteristics of latrines and single faeces. Chemoecology 16:219-222

Barja I, Silván G, Martínez-Fernández L, Illera JC (2011) Physiological stress responses, fecal marking behavior, and reproduction in wild European pine martens (Martes martes). J Chem Ecol 37:253-259

Barrientos R (2006) Year-round defecation pattern in wild genets (Genetta genetta L.) in a mountain forest (Toledo, Central Spain). Pol J Ecol 54:325-328

Barry RE, Shoshani J (2000) Mammal species: Heterohyrax brucei. Mamm Species 645:1-7

Bates D, Maechler M, Bolker B (2012) lme4: Linear mixed effects models using S4 classes. R package version 1.0-5. http://CRAN.Rproject.org/package $=$ lme 4

Bearder SW, Randall RM (1978) The use of fecal marking sites by spotted hyenas and civets. Carnivore 1:32-48

Black-Decima P, Santana M (2011) Olfactory communication and counter-marking in brown brocket deer Mazama gouazoubira. Acta Theriol 56:179-187

Bolker BM, Brooks ME, Clark CJ, Geange SW, Poulsen JR, Stevens MHH, White J-SS (2008) Generalized linear mixed models: a practical guide for ecology and evolution. Trends Ecol Evol 24:127-135

Boulet M, Charpentier MJE, Drea CM (2009) Decoding an olfactory mechanism of kin recognition and inbreeding avoidance in a primate. BMC Evol Biol 9:281

Boulet M, Crawford JC, Charpentier MJE, Drea CM (2010) Honest olfactory ornamentation in a female-dominant primate. J Evol Biol 23:1558-1563

Brady KM, Armitage KB (1999) Scent-marking in the yellow-bellied marmot (Marmota flaviventris). Ethol Ecol Evol 11:35-47

Branch LC (1993) Social organization and mating system of the plains viscacha (Lagostomus maximus). J Zool 229:473-491

Brashares JS, Arcese P (1999) Scent marking in a territorial African antelope: II. The economics of marking with faeces. Anim Behav 57:11-17

Bravo SP, Zunino GE (2000) Germination of three arboreal seeds dispersed by black howler monkeys (Alouatta caraya). Folia Primatol 71:342-345

Brown RE, Macdonald DW (1985) Social odours in mammals, vol II. Clarendon Press, Oxford

Brown JA, Cheeseman CL, Harris S (2009) Studies on the spread of bovine tuberculosis from badgers to cattle. J Zool 227:694-696

Candiotti A, Zuberbühler K, Lemasson A (2012) Convergence and divergence in Diana monkey vocalizations. Biol Lett 8:382-385

Caspers BA, Schroeder FC, Franke S, Streich WJ, Voigt CC (2009) Odour-based species recognition in two sympatric species of sacwinged bats (Saccopteryx bilineata, S. leptura): combining chemical analyses, behavioural observations and odour preference tests. Behav Ecol Sociobiol 63:741-749

Charles-Dominique P, Hladik CM (1971) Le Lepilemur du sud de Madagascar: ecologie, alimentation, et vie sociale. Terre Vie-Rev Ecol A 25:3-66

Charpentier MJE, Boulet M, Drea CM (2008) Smelling right: the scent of male lemurs advertises genetic quality and relatedness. Mol Ecol 17: 3225-3233

Charpentier MJE, Crawford JC, Boulet M, Drea CM (2010) Message "scent": lemurs detect the genetic relatedness and quality of conspecifics via olfactory cues. Anim Behav 80:101-108

Converse LJ, Carlson AA, Ziegler TE, Snowdon CT (1995) Communication of ovulatory state to mates by female pygmy marmosets, Cebuella pygmaea. Anim Behav 49:615-621

Crawford JC, Charpentier MJE, Boulet M, Drea CM (2009) Lemurs discriminate the scent of conspecifics based on individual heterozygosity and pairwise relatedness. Integr Comp Biol 49:E41

Cushing BS (1984) A selective preference by least weasels for oestrous versus dioestrous urine of prairie deer mice. Anim Behav 32:12631265 
Darden SK, Steffensen LK, Dabelsteen T (2008) Information transfer among widely spaced individuals: latrines as a basis for communication networks in the swift fox? Anim Behav 75:425-432

Davies JM, Lachno DR, Roper TJ (1988) The anal gland secretion of the European badger (Meles meles) and its role in social communication. J Zool 216:455-463

De Solla SR, Bonduriansky R, Brooks RJ (1999) Eliminating autocorrelation reduces biological relevance of home range estimates. J Anim Ecol 68:221-234

Delbarco-Trillo J, Burkert BA, Goodwin TE, Drea CM (2001) Night and day: the comparative study of strepsirrhine primates reveals socioecological and phylogenetic patterns in olfactory signals. Evol Biol 24:82-98

Dinerstein E, Wemmer CM (1988) Fruits rhinoceros eat: dispersal of Trewia nudiflora. Ecology 69:1768-1774

Dixon PM (2002) Ripley's K Function. In: El-Shaarawi AH, Piegorsch WW (eds) Encyclopedia of environmetrics, vol 3. Wiley, Chichester, pp 1796-1803

Dröscher I, Kappeler PM (2013) Defining the low end of primate social complexity: the social organization of the nocturnal white-footed sportive lemur (Lepilemur leucopus). Int J Primatol 34:1225-1243

Dröscher I, Kappeler PM (2014) Competition for food in a solitarily foraging folivorous primate (Lepilemur leucopus)? Am J Primatol $76: 842-854$

Dubost G (1970) L'organisation spatiale et sociale de Muntiacus reevesi Ogilby 1839 en semi-liberté. Mammalia 34:331-355

Dubost G (1971) Observations ethologiques sur le muntjak (Muntiacus muntjak Zimmerman 1780 et $M$. reevesi Ogilby 1839) en captivité et semi-liberté. Z Tierpsychol 28:387-427

Eisenberg JF, Kleiman DG (1972) Olfactory communication in mammals. Annu Rev Ecol Syst 3:1-32

Epple G (1986) Communication by chemical signals. In: Mitchell G, Erwin J (eds) Comparative primate biology 2A. Liss, New York, pp 531-580

Eppley TM, Donati G (2010) Observations of terrestrial latrine behaviour by the southern gentle lemur Hapalemur meridionalis in the Mandena littoral forest, southeast Madagascar. Lemur News 15:51-54

Essghaier FA, Johnson R (1981) Distribution and use of dung heaps by Dorcas gazelle in western Lybia. Mammalia 45:153-155

Estes RD (1991) The behavior guide to African mammals. University of California Press, Berkeley

Ferkin MH, Johnston RE (1995) Meadow voles, Microtus pennsylvanicus, use multiple sources of scent for sex recognition. Anim Behav 49:37-44

Fichtel C, Hilgartner R (2013) Noises in the dark: Vocal communication in Lepilemur ruficaudatus and other nocturnal pair-living primates. In: Masters J, Gamba M, Genin F (eds) Leaping ahead. Advances in prosimian biology. Springer, New York, pp 297-304

Field A, Miles J, Field Z (2012) Discovering statistics using R. Sage, Los Angeles

Fox J, Weisberg S (2011) An R companion to applied regression. Sage, Thousand Oaks

Fragoso JM, Silvius VKM, Correa LA (2003) Long-distance seed dispersal by tapirs increases seed survival and aggregates tropical trees: long-distance dispersal. Ecology 84:1998-2006

Franklin SP, Miller KE, Baker AJ, Dietz JM (2007) Do cavity-nesting primates reduce scent marking before retirement to avoid attracting predators to sleeping sites? Am J Primatol 69:255-266

Geissmann T, Orgeldinger M (2000) The relationship between duet songs and pair bonds in siamangs, Hylobates syndactylus. Anim Behav 60: 805-809

Ghosal R, Seshagiri PB, Sukumar R (2012) Dung as a potential medium for inter-sexual chemical signaling in Asian elephants (Elephas maximus). Behav Process 91:15-21

González-Zamora A, Arroyo-Rodríguez V, Oyama K, Sork V, Chapman CA, Stoner KE (2012) Sleeping sites and latrines of spider monkeys in continuous and fragmented rainforests: implications for seed dispersal and forest regeneration. PLoS ONE 7:e46852
Gorman ML, Mills MGL (1984) Scent marking strategies in hyaenas (Mammalia). J Zool 202:535-547

Gosling LM (1974) The social behaviour of Coke's hartebeest (Alcelaphus buselaphus cokei). In: Geist V, Walther F (eds) The behaviour of ungulates and its relation to management, vol 2, IUCN publication. Morges, Switzerland, pp 759-786

Gosling LM (1987) Scent marking in an antelope lek territory. Anim Behav 35:620-622

Gosling LM, Wright KHM (1994) Scent marking and resource defence by male coypus (Myocastor coypus). J Zool 234:423-436

Goszczynski J (1990) Scent marking by red foxes in Central Poland during the winter season. J Acta Theriol 35:7-16

Green MJB (1987) Scent-marking in the Himalayan musk deer (Moschus chrysogaster). J Zool 1:721-737

Greene LK, Drea CM (2014) Love is in the air: sociality and pair bondedness influence sifaka reproductive signalling. Anim Behav $88: 147-156$

Grubb P (2003) Interpreting some outstanding features of the flora and vegetation of Madagascar. Perspect Plant Ecol Evol Syst 6:125-146

Hendrichs H, Hendrichs U (1971) Freilanduntersuchungen zur Ökologie und Ethologie der Zwerg-Antilope Madoqua (Rhynchotragus) kirki (Günther 1880). In: Hendrichs H, Hendrichs U (eds) Dikdik und Elefanten. Piper, Munich, pp 9-75

Henriquez JM (2004) Camelid defecation influences vegetation development and species richnesss on glacial moraines, Tierra del Fuego. Rev Chil Hist Nat 77:501-508

Heymann EW (1998) Sex differences in olfactory communication in a primate, the moustached tamarin, Saguinus mystax (Callitrichinae). Behav Ecol Sociobiol 43:37-45

Heymann EW (2006a) Scent marking strategies of new world primates. Am J Primatol 68:650-661

Heymann EW (2006b) The neglected sense - olfaction in primate behavior, ecology, and evolution. Am J Primatol 69:519-524

Hilgartner R, Zinner D, Kappeler P (2008) Life history traits and parental care in Lepilemur ruficaudatus. Am J Primatol 70:2-11

Hilgartner R, Fichtel C, Kappeler PM, Zinner D (2012) Determinants of pair-living in red-tailed sportive lemurs (Lepilemur ruficaudatus). Ethology 118:466-479

Hladik CM, Charles-Dominique P (1974) The behavior and ecology of the sportive lemur (Lepilemur mustelinus) in relation to its dietary peculiarities. In: Martin RD, Doyle GA, Walker AC (eds) Prosimian biology. Duckworth, London, pp 23-37

Hogan LA, Lisle AT, Johnston SD (2013) Eliminative behavior of captive numbats, Myrmecobius fasciatus (Mammalia; Marsupialia): pattern and identification of fecal deposits. Zoo Biol 32:324-331

Hooge PN, Eichenlaub B (1997) Animal movement extension to arcview Version 1.1. U.S. Geological Survey, Alaska Science CenterBiological Science Office, Anchorage

Hulsman A, Dalerum F, Swanepoel L, Ganswindt A, Sutherland C, Paris M (2010) Patterns of scat deposition by brown hyaenas Hyaena brunnea in a mountain savannah region of South Africa. Wildl Biol $16: 445-451$

Ikeda H (1984) Racoon dog scent marking by scats and its significance in social behaviour. J Ethol 2:77-84

Irwin MT, Samonds KE, Raharison J-L, Wright PC (2004) Lemur latrines: observations of latrine behavior in wild primates and possible ecological significance. J Mammal 85:420-427

Jannett FJ Jr (1986) Morphometric patterns among microtine rodents. I. Sexual selection suggested by relative scent gland development in representative voles (Microtus). In: Duvall D, Müller-Schwarze D, Silverstein RM (eds) Chemical signals in vertebrates 4. Plenum, New York, pp 541-550

Jordan NR, Cherry MI, Manser MB (2007) Latrine distribution and patterns of use by wild meerkats: implications for territory and mate defence. Anim Behav 73:613-622 
Julliot C (1996) Seed dispersal by red howling monkeys (Alouatta seniculus) in the tropical rain forest of French Guiana. Int $\mathrm{J}$ Primatol 17:239-258

Kappeler PM (1998) To whom it may concern: the transmission and function of chemical signals in Lemur catta. Behav Ecol Sociobiol 42:411-421

Kappeler PM, van Schaik CP (2002) The evolution of primate social systems. Int J Primatol 23:707-740

Kilshaw K, Newman C, Buesching C, Bunyan J, Macdonald D (2009) Coordinated latrine use by European badgers, Meles meles: potential consequences for territory defense. J Mammal 90:1188-1198

Kingdon J (1982) East African mammals. Atlas of evolution in Africa, Volume 3, Part C. University of Chicago Press, Chicago

Klingel (1974) A comparison of the social behaviour of the Equidae. In: Geist V, Walther FR (eds) The behaviour of ungulates and its relation to management. IUCN Publ, pp 124-132

Kruuk H (1992) Scent marking by otters (Lutra lutra): signaling the use of resources. Behav Ecol 3:133-140

Kuznetsova A, Brockhoff PB, Christensen RHB (2014) lmerTest: Tests for random and fixed effects for linear mixed effect models (lmer objects of lme4 package). R package version 2.0-6. http://CRAN.Rproject.org/package $=$ lmerTest

Lazaro-Perea C, Snowdon CT, de Fátima AM (1999) Scent-marking behavior in wild groups of common marmosets (Callithrix jacchus). Behav Ecol Sociobiol 46:313-324

Leuchtenberger C, Mourão G (2009) Scent-marking of giant otter in the Southern Pantanal, Brazil. Ethology 115:210-216

Lewis RJ (2005) Sex differences in scent-marking in sifaka: mating conflict or male services? Am J Phys Anthropol 128:389-398

Lewis RJ (2006) The function of scent-marking in sifaka (Propithecus verreauxi verreauxi). Am J Primatol 68:622-636

Linklater WL, Mayer K, Swaisgood RR (2013) Chemical signals of age, sex and identity in black rhinoceros. Anim Behav 85: 671-677

Macdonald DW (1980) Patterns of scent marking with urine and faeces amongst carnivore communities. Symp Zool Soc Lond 45:107-139

MacNamara M, Eldridge WD (1987) Behavior and reproduction in captive pudu (Pudu puda) and red brocket (Mazama americana): a descriptive and comparative analysis. In: Wemmer C (ed) Biology and management of the Cervidae. Smithsonian Institution, Washington, pp 371-387

McGregor BA, Brown AJ (2010) Soil nutrient accumulation in alpaca latrine sites. Small Rumin Res 94:17-24

Meadows ME, Chase BM, Seliane M (2010) Holocene palaeoenvironments of the Cederberg and Swartruggens mountains, Western Cape, South Africa: pollen and stable isotope evidence from hyrax dung middens. J Arid Environ 74:786-793

Méndez-Cárdenas MG, Zimmermann E (2009) Duetting — a mechanism to strengthen pair bonds in a dispersed pair-living primate (Lepilemur edwardsi)? Am J Phys Anthropol 139:523-532

Mertl AS (1976) Olfactory and visual cues in social interactions of Lemur catta. Folia Primatol 26:151-161

Mertl-Milhollen AS (1979) Olfactory demarcation of territorial boundaries by a primate - Propithecus verreauxi. Folia Primatol 32:35-42

Miller KE, Laszlo K, Dietz JM (2003) The role of scent marking in the social communication of wild golden lion tamarins, Leontopithecus rosalia. Anim Behav 65:795-803

Mills MGL, Gorman ML (1987) The scent-marking behaviour of the spotted hyaena Crocuta crocuta in the southern Kalahari. J Zool 212:483-497

Mills MGL, Gorman ML, Mills MEJ (1980) The scent-marking behaviour of the brown hyaena Hyaena brunnea. S Afr J Zool 15:240-248

Milner J, Harris S (1999) Habitat use and ranging behaviour of tree hyrax, Dendrohyrax arboreus, in the Virunga Volcanoes, Rwanda. Afr J Ecol 37:281-294
Morelli TL, Hayes RA, Nahrung HF, Goodwin TE, Harelimana IH, Macdonald LJ, Wright PC (2013) Relatedness communicated in lemur scent. Naturwissenschaften 100:769-777

Müller CA, Manser MB (2007) 'Nasty neighbours' rather than 'dear enemies' in a social carnivore. Proc R Soc Lond B 274:959-965

Nel JAJ, Bothma JDP (2002) Scent marking and midden use by aardwolves (Proteles cristatus) in the Namib Desert. J Ecol 21:25-39

Nieuwenhuis R, te Grotenhuis M, Pelzer B (2012) Influence.ME: Tools for detecting influential data in mixed effects models. R Journal 4: $38-47$

Norscia I, Palagi E (2008) Berenty 2006: census of Propithecus verreauxi and possible evidence of population stress. Int J Primatol 29:1099 1115

Oakwood M (2002) Spatial and social organization of a carnivorous marsupial Dasyurus hallucatus (Marsupialia: Dasyuridae). J Zool 257:237-248

Oldham AR, Black JM (2009) Experimental tests of latrine use and communication by river otters. Northwest Nat 90:207-211

Ono Y, Dói T, Ikeda H, Baba M, Takeishi M, Izawa M, Iwamoto T (1988) Territoriality of Guenther's dikdik in the Omo National Park, Ethiopia. Afr J Ecol 26:33-49

Owen-Smith RN (1975) The social ethology of the white rhinoceros, Ceratotherium simum (Burchell, 1812). Z Tierpsychol $38: 337-384$

Palphramand KL, White PCL (2007) Badgers, Meles meles, discriminate between neighbour, alien and self scent. Anim Behav 74:429-436

Pemberton D (1990) Social organisation and behaviour of the Tasmanian devil, Sarcophilus harrisii. PhD Thesis, University of Tasmania

Perret M (1992) Environmental and social determinants of sexual function in the male lesser mouse lemur (Microcebus murinus). Folia Primatol 59:1-25

Peters RP, Mech LD (1975) Scent-marking in wolves. Sci Am 63:628637

Petter JJ (1962) Recherches sur l'ecologie et l'ethologie des lemuriens malgaches. Mem Mus Hist Nat Zool 27:1-146

Petter JJ, Albignac R, Rumpler Y (1977) Faune de Madagascar 44: mammifères lé muriens (Primates Prosimiens). ORSTROM/ CNRS, Paris

Pigozzi G (1989) Latrine use and the function of territoriality in the European badger, Meles meles, in a mediterranean coastal habitat. Anim Behav 39:1000-1002

Quinn GP, Keough MJ (2002) Experimental designs and data analysis for biologists. Cambridge University Press, Cambridge

Qureshi BD, Awan MS, Khan AA, Dar NI, Dar MEI (2004) Distribution of Himalayan Musk deer (Moschus chrysogaster) in Neelum Valley, District Muzaffarabad, Azad Jammu and Kashmir. J Biol Sci 4:258-261

Ralls K (1971) Mammalian scent marking. Science 171:443-449

Ralls K, Smith DA (2004) Latrine use by San Jaoquin kit foxes (Vulpes macrotis mutica) and coyotes (Canis latrans). West N Am Nat 64: 644-647

Randrianambinina B, Mbotizafy S, Rasoloharijaona S, Ravoahangimalala RO, Zimmermann E (2007) Seasonality in reproduction of Lepilemur edwardsi. Int J Primatol 28:783-790

Rasmussen LE, Schmidt MJ, Henneous R, Groves D, Daves GD Jr (1982) Asian bull elephants: Flehmen-like responses to extractable components in female elephant estrous urine. Science 217:159-162

Rasoloharijaona S, Rakotosamimanana B, Randrianambinina B, Zimmermann E (2003) Pair-specific usage of sleeping sites and their implications for social organization in a nocturnal Malagasy primate, the Milne Edwards' sportive lemur (Lepilemur edwardsi). Am J Phys Anthropol 122:251-258

Rasoloharijaona S, Randrianambinina B, Braune P, Zimmermann E (2006) Loud calling, spacing, and cohesiveness in a nocturnal primate, the Milne Edwards' Sportive Lemur (Lepilemur edwardsi). Am J Phys Anthropol 129:591-600 
Rasoloharijaona S, Randrianambinina B, Zimmermann E (2008) Sleeping site ecology in a rain-forest dwelling nocturnal lemur (Lepilemur mustelinus): implications for sociality and conservation. Am J Primatol 70:247-253

Rasoloharijaona S, Randrianambinina B, Joly-Radko M (2010) Does nonnutritive tree gouging in a rainforest-dwelling lemur convey resource ownership as does loud calling in a dry forest-dwelling lemur? Am J Primatol 72:1062-1072

R Core Team (2012) R: a language and environment for statistical computing. R Foundation for Statistical Computing, Vienna, Austria, http://www.R-project.org/

Remonti L, Balestrieri A, Smiroldo G, Prigioni C (2011) Scent marking of key food sources in the Eurasian otter. Ann Zool Fenn 48:287-294

Rich T, Hurst J (1998) Scent marks as reliable signals of the competitive ability of mates. Anim Behav 56:727-735

Rivero CK, Rumiz DL, Taber AB (2004) Estimating brocket deer (Mazama gouazoubira and M. americana) abundance by dung pellet counts and other indices in seasonal Chiqitano forest habitats of Santa Cruz, Bolivia. Eur J Wildl Res 50:161-167

Roberts SC, Lowen C (1997) Optimal patterns of scent marks in klipspringer (Oreotragus oreotragus) territories. J Zool 243:565-578

Rooney SM, Wolfe A, Hayden TJ (1998) Autocorrelated data in telemetry studies: time to independence and the problem of behavioural effects. Mamm Rev 28:89-98

Roper TJ, Shepherdson DJ, Davies JM (1986) Scent marking with faeces and anal secretion in the European badger. Behaviour 97:94-117

Roper TJ, Conradt L, Butler J, Christian SE, Ostler J, Schmid TK (1993) Territorial marking with faeces in badgers (Meles meles): a comparison of boundary and hinterland latrine use. Behaviour 127:289-307

Rostain RR, Ben-David M, Groves P, Randall JA (2004) Why do river otters scent-mark? An experimental test of several hypotheses. Anim Behav 68:703-711

Ruibal M, Peakall R, Claridge A (2010) Socio-seasonal changes in scent marking habits in the carnivorous marsupial Dasyurus maculatus at communal latrines. Aust J Zool 58:317-322

Runcie MJ (2004) Scent-marking and vocal communication in the rock haunting possum Petropseudes dahli. In: Goldingay RL, Jackson SM (eds) The biology of Australian possums and gliders. Surrey Beatty and Sons, Sydney, pp 401-412

Russel RJ (1977) The behavior, ecology and environmental physiology of a nocturnal primate, Lepilemur mustelinus (Strepsirhini, Lemuriformes, Lepilemuridae). PhD Thesis, Duke University

Schielzeth H (2010) Simple means to improve the interpretability of regression coefficients. Methods Ecol Evol 1:103-113

Schilling A (1979) Olfactory communication in prosimians. In: Doyle GA, Martin RD (eds) The study of prosimian behavior. Academic, New York, pp 461-542

Schilling A (1980a) Seasonal variation in the fecal marking of Cheirogaleus medius in simulated climatic conditions. In: Charles-Dominique P, Cooper HM, Hladik A et al (eds) Nocturnal Malagasy primates: ecology, physiology and behavior. Academic, New York, pp 181-190

Schilling A (1980b) The possible role of urine in territoriality of some nocturnal prosimians. Symp Zool Soc Lond 45:165-193

Schülke O, Kappeler PM (2003) So near and yet so far: territorial pairs but low cohesion between pair partners in a nocturnal lemur, Phaner furcifer. Anim Behav 65:331-343

Serena M, Soderquist TR (1989) Spatial organisation of a riparian population of the carnivorous marsupial Dasyurus geoffroii. J Zool 219: $373-383$

Sewall KB (2009) Limited adult vocal learning maintains call dialects but permits pair-distinctive calls in red crossbills. Anim Behav 77: $1303-1311$

Sillero-Zubiri C, Macdonald DW (1998) Scent-marking and territorial behaviour of Ethiopian wolves Canis simensis. J Zool 245:351-361
Silverman BW (1986) Density estimation for statistics and data analyses. Chapman and Hall, London

Smith JLD, McDougal C, Miquelle D (1989) Scent marking in freeranging tigers, Panthera tigris. Anim Behav 37:1-10

Sneddon IA (1991) Latrine use by the European rabbit (Oryctolagus cuniculus). J Mammal 72:769e775

Stewart PD, Macdonald DW, Newman C, Cheeseman CL (2001) Boundary faeces and matched advertisement in the European badger (Meles meles): a potential role in range exclusion. J Zool 255:191-198

Stewart PD, Macdonald DW, Newman C, Tattersall FH (2002) Behavioural mechanisms of information transmission and reception by badgers, Meles meles, at latrines. Anim Behav 63:999-1007

Sun L, Xiao B, Dai N (1994) Scent marking behaviour in the male Chinese water deer. Acta Theriol 39:177-184

Topp-Jørgensen JE, Marshall AR, Brink H, Pedersen UB (2008) Quantifying the response of tree hyraxes (Dendrohyrax validus) to human disturbance in the Udzungwa Mountains, Tanzania. Trop Conserv Sci 1:63-74

Trapp GR (1978) Comparative behavioral ecology of the ringtail and the gray fox in Southwestern Utah. Carnivore 1:3-31

Trumler E (1958) Beobachtungen an den Bohmzebras des "Georg von Opel-Freigeheges für Tierforschung e V". Kronberg im Taunus. I. Das Paarungsverhalten. Säugetierkd Mitt 6:1-48

Tyack PL (2008) Convergence of calls as animals form social bonds, active compensation for noisy communication channels, and the evolution of vocal learning in mammals. J Comp Psychol 122:319-331

Vander Wal E, Rodgers AR (2012) An individual-based quantitative approach for delineating core areas of animal space use. Ecol Model 224:48-53

Venables WN, Ripley BD (2002) Modern applied statistics with S, 4th edn. Springer, New York

Viitala J, Korpimäki E, Palokangas P, Koivula M (1995) Attraction of kestrels to vole scent marks visible in ultraviolet light. Nature 373:425-427

Walther F (1978) Mapping the structure and the marking system of a territory of the Thomson's gazelle. E Afr Wildl J 16:167-176

Wemmer C, Montali R (1988) Latrine use and the subcaudal gland of the brow-antlered deer (Cervus eldi thamin). J Mammal 69:815-818

Wolff J, Mech SG, Thomas SA (2002) Scent marking in female Prairie voles: a test of alternative hypotheses. Ethology 108:483-494

Woodroffe GL, Lawton JH (1990) Patterns in the production of latrines by water voles (Arvicola terrestris) and their use as indices of abundance in population surveys. J Zool 220:439-445

Worton BJ (1989) Kernel methods for estimating the utilization distribution in home-range studies. Ecology 70:164-168

Wronski T, Plath M (2010) Characterization of the spatial distribution of latrines in reintroduced mountain gazelles: do latrines demarcate female group home ranges? J Zool 280:92-101

Wronski T, Apio A, Plath M (2006) The communicatory significance of localised defecation sites in bushbuck (Tragelaphus scriptus). Behav Ecol Sociobiol 60:368-378

Wronski T, Apio A, Plath M, Ziege M (2013) Sex difference in the communicatory significance of localized defecation sites in Arabian gazelles (Gazella arabica). J Ethol 31:129-140

Ydenberg RC, Giraldeau LA, Falls JB (1988) Neighbors, strangers, and the asymmetric war of attrition. Anim Behav 36:343-347

Yumoto T, Kimura K, Nishimura A (1999) Estimation of the retention times and distances of seed dispersed by two monkey species, Alouatta seniculus and Lagothrix lagothricha, in a Colombian forest. Ecol Res 14:179-191

Ziegler TE (2013) Social effects via olfactory sensory stimuli on reproductive function and dysfunction in cooperative breeding marmosets and tamarins. Am J Primatol 75:202-211

Zinner D, Hilgartner RD, Kappeler PM, Pietsch T, Ganzhorn JU (2003) Social organization of Lepilemur ruficaudatus. Int J Primatol 24: 869-888 